J. Clin. Chem. Clin. Biochem.

Vol. 24, 1986, pp. $541-549$

(C) 1986 Walter de Gruyter \& Co.

Berlin - New York

\title{
Functional Analysis of Plasma Fibronectin with Special Consideration of Binding Interferences
}

\author{
By E. Köttgen, S. Hoeft, Ch. Müller and B. Hell \\ Institut für Klinische Chemie und Biochemie, Klinikum Charlottenburg, Freie Universität Berlin, Berlin, FRG
}

(Received January 17/March 24, 1986)

Dedicated to Prof. Dr. W. Gerok on the occasion of his 60th birthday

Summary: So far, soluble fibronectin has been quantitated mostly by immunological techniques. In this investigation we show that an immunological assay provides reliable results only with intact fibronectin. Fibronectin fragments resulting from proteolysis give rise to falsely raised values. We present four functional tests based on the sandwich (ELISA) technique on microtitre plates. These quantify fibronectin on the basis of its binding capacity to collagen, heparin, fibrin and carboxy-group-modified IgG with high sensitivity, specificity and precision. Analysis of the bioactivity spectrum of intact fibronectin is not disturbed by fibronectin fragments. Furthermore we demonstrate interferences, in particular between heparin and collagen in their mutual binding to fibronectin. This provides new indications of a "substrate activation" of fibronectin.

Funktionsorientierte Quantifizierung von Fibronectin unter besonderer Berücksichtigung von Bindungsinterferenzen

Zusammenfassung: Die Quantifizierung von löslichem Fibronectin im Plasma erfolgt bisher weitgehend über rein immunologische Verfahren. In der vorliegenden Untersuchung wird gezeigt, daß diese immunologische Konzentrationsbestimmung nur bei intaktem Fibronectin korrekte Ergebnisse ergibt. Proteolytische Fibronectin-Fragmente liefern falsch erhöhte Werte. Als Alternative zur immunologischen Konzentrationsbestimmung werden vier Fibronectin-Funktionsteste nach der Sandwich-(ELISA-) Technik auf Mikrotiterplatten vorgestellt, die die Bindungskapazität von Fibronectin gegenüber Kollagen, Heparin, Fibrin und Carboxygruppenmodifiziertem IgG mit hoher Nachweisempfindlichkeit, Spezifität und Präzision quantifizieren. Die Analyse des Fibronectin-Bindungsspektrums wird nicht durch Fibronectin-Fragmente gestört. Zwischen immunologischer und biologischer Reaktivität bestehen daher nur bei intakter Proteinstruktur Beziehungen. Weiterhin werden Interferenzen insbesondere zwischen der Heparin- und der Kollagen-Bindung demonstriert, die erneut Hinweise auf eine „Substrat-Aktivierung“ von Fibronectin geben.

\section{Introduction}

Fibronectin is the term used today for a high molecular weight glycoprotein, which has previously been known under various names. The protein is of great interest for biochemical studies in cell biology and medicine $(1,2,3)$. The molecule is synthesized by various types of cells and is localized on the cell surface as a fibrillar polymer. The soluble plasma fibronectin $\left(M_{\mathrm{r}}=\right.$ ca. 440000$)$ is a dimer with two polypeptide chains connected via two disulphide bridges. Additional intrachain S-S bridges contribute to the formation of a typical tertiary structure characterized by four globular domains with protease-sensitive connecting units. The glycosylation and phosphorylation of the protein can show maturation- and organ-specific variations $(3,5,6)$. 
The domains mentioned above can be isolated by limited proteolysis $(7,8)$. The domains are characterized by their differing capacity for binding primarily either collagen, glycosaminoglycans (especially heparin) and fibrin, with additional affinities to complement factor $\mathrm{Clq}$, actin, DNA and gangliosides. The C-terminal domain additionally binds proteins with modified carboxyl groups such as $\operatorname{IgG}(9,10)$.

Due to these multiple ligand properties, fibronectin is involved in many biological functions, such as cell adhesion, chemotaxis, immunomodulation, bacterial tissue tropism, wound repair and in blood coagulation (2). Fibronectin is gaining additional medical significance, since appreciable alterations of the plasma fibronectin concentrations can be observed in the plasma of patients with inflammatory diseases as well as in shock patients $(11,12,13)$.

In addition, 'the differentiation of a 'malignant' from a 'benign' ascites is possible by determining the fibronectin concentration in ascites (14). However, the majority of these results is based exclusively on immunological quantification of fibronectin in which altered functionality of the various domains is not reflected. Furthermore, these investigations do not take into consideration the extent to which functionreduced proteolytic fibronectin fragments may influence the quantitation of intact fibronectin. Enhanced proteolytic activity can be found for example in malignant ascites, as well as in the plasma of patients with acute pancreatitis or disseminated intravascular coagulation with fibrinolytic states.

In the results presented, we describe a test battery based on an ELISA-equivalent test procedure enabling quantification of four domain-specific functions of fibronectin. Furthermore, we present comparative investigations on functional interference with the fibronectin binding capacity.

\section{Materials and Methods}

Rabbit anti-human fibronectin and rabbit anti-human-fibronectin-peroxidase conjugate were obtained from Dakopatts (Copenhagen, Denmark), thermolysin from Boehringer (Mannheim, FRG), thrombin from Behringwerke (Marburg, FRG), bovine serum albumin and 3,3',5,5'-tetramethylbenzidine from Miles Lab. (Munich, FRG), and hydroxyapatite (DNA grade) from Bio Rad (Munich, FRG). $\varepsilon$-Aminocaproic acid, heparin-agarose, peroxidase, heparin-sodium salt, gelatine (calf skin), fibrinogen (bovine), glycine ethyl ester, Tween 20 and 3-amino-9-ethylcarbazole were obtained from Sigma (Munich, FRG), gelatine-sepharose from Pharmacia (Uppsala, Sweden), nitrocellulose membranes $(0.45 \mu \mathrm{m}$ pore size) from Biotec Fischer (Reiskirchen, FRG). All other reagents were purchased as analytical grade from E. Merck (Darmstadt, FRG).
For the ELISA technique, immuno-microtitre plates from NUNC (Wiesbaden, FRG) and Titertek-Multiscan (Flow Labs.) were used. For the polyacrylamide gel electrophoresis, the flat bed gel electrophoresis from Pharmacia, and for the Western blot the Biotec Fischer (FRG) facility was applied.

\section{Buffers}

(i) Phosphate buffer: $57,9 \mathrm{mmol} / \mathrm{l} \quad \mathrm{Na}_{2} \mathrm{HPO}_{4}, 8.8 \mathrm{mmol} / \mathrm{l}$ $\mathrm{KH}_{2} \mathrm{PO}_{4}, \mathrm{pH} 7.6$;

(ii) Phosphate buffer, containing bovine serum albumin and EDTA: phosphate buffer (i) $+5 \mathrm{mmol} / 1$ EDTA $+5 \mathrm{~g} / \mathrm{l}$ bovine serum albumin;

(iii) Phosphate buffer, containing Tween: phosphate buffer (i) $+0.5 \mathrm{~g} / 1$ Tween 20 ;

(iv) blotting transfer buffer: $12.5 \mathrm{mmol} / 1 \mathrm{Tris}, 96 \mathrm{mmol} / 1$ glycine, $0.1 \mathrm{~g} / \mathrm{l} \mathrm{SDS}, 200 \mathrm{~g} / \mathrm{l}$ methanol, pH 8.3;

(v) blocking buffer (Western blot): $10.0 \mathrm{mmol} / 1$ Tris, $150 \mathrm{mmol} / 1$ $\mathrm{NaCl} .5 \mathrm{~g} / \mathrm{l}$ bovine serum albumin, $0.5 \mathrm{~g} / 1$ Tween $20, \mathrm{pH} 7.4$.

\section{Fibronectin isolation}

Fibronectin was prepurified from citrate-plasma by affinity chromatography on gelatine-sepharose in buffer (i) with 10 $\mathrm{mmol} / \mathrm{l} \varepsilon$-aminocaproic acid, $5.0 \mathrm{mmol} / \mathrm{l}$ EDTA followed by a specific elution with $50 \mathrm{mmol} / \mathrm{l}$ Tris, $4 \mathrm{~mol} / \mathrm{l}$ urea, pH 7.6.

The fibronectin was additionally purified on heparin-sepharose (washing buffer: $10 \mathrm{mmol} / 1$ Tris, $\mathrm{pH} 7.6$; elution: $10 \mathrm{mmol} / 1$ Tris, $0.5 \mathrm{~mol} / 1 \mathrm{NaCl}$, pH 7.6) (15). In the SDS-polyacrylamide gel electrophoresis, the typical double bands are found exclusively at $M_{\mathrm{r}}=220000$. The protein determination is carried out according to Lowry or by photometric measurement at 280 $\mathrm{nm}$ (fibronectin $\left.[10 \mathrm{~g} / \mathrm{l}] \mathrm{A}_{280}\langle 1 \mathrm{~cm}\rangle=12.8\right)(16)$. After addition of $\mathrm{NaN}_{3}(0.1 \mathrm{~g} / \mathrm{l})$ the purified protein can be stored at $4^{\circ} \mathrm{C}$ for at least eight weeks.

\section{Fibronectin proteolysis}

Thermolysin and fibronectin $1: 200$ (weight ratio) were incubated for different times (see results) at $20^{\circ} \mathrm{C}$ in $60 \mathrm{mmol} / 1$ Tris, $3.0 \mathrm{mmol} / 1 \mathrm{CaCl}_{2}, \mathrm{pH} 7.6$ (7). The proteolysis is terminated by addition of $0.2 \mathrm{~mol} / \mathrm{l}$ EDTA (final concentration in the test mixture $10 \mathrm{mmol} / \mathrm{l}$ EDTA).

\section{Polyacrylamide gel electrophoresis}

The SDS-polyacrylamide gel electrophoresis was carried out under reducing conditions in the buffer system according to Laemmli (20) with a $3.5 \%$ stacking gel, a linear gradient-gel $(5-12 \%)$ and a separation distance of $13 \mathrm{~cm}$. The proteins were fixed and stained in a solution containing acetic acid (70 $\mathrm{g} / \mathrm{l})$ - methanol $(1+2$ by vol.) and Coomassie blue $(1.0 \mathrm{~g} / \mathrm{l})$.

\section{Western blot}

Proteins were transferred from the polyacrylamide gel electrophoretically at 100 volts for one hour onto nitrocellulose sheets according to Towbin (19). After blocking the free binding sites on the nitrocellulose membrañe for $16 \mathrm{~h}$ (blocking buffer see above), the membrane was incubated for $1 \mathrm{~h}$ with shaking in a $1: 1000$ dilution (by vol.) of peroxidase-labeled antibody in buffer (ii). After washing three times in buffer (iii), the membrane was stained with aminoethylcarbazole. 


\section{Hydroxyapatite chromatography}

Fibronectin was equilibrated in washing buffer $(2 \mathrm{mmol} / \mathrm{l}$ sodium phosphate buffer, $1 \mathrm{mmol} / \mathrm{l}$ EDTA, pH 6.8) and $100 \mathrm{mg}$ protein was applied to the column $(1.5 \times 25 \mathrm{~cm})$. The specific elution was carried out in a linear gradient up to $200 \mathrm{mmol} / \mathrm{l}$ sodium phosphate (18).

\section{Enzyme-linked-immuno-sorbent-assays (ELISA)}

The assays were performed in accordance with the "sandwich technique" with biological ligands fixed to polystyrene. For detection of bound fibronectin, peroxidase-conjugated antifibronectin was used. Tetramethylbenzidine $(80 \mathrm{mg} / \mathrm{l}$ dissolved in $160 \mathrm{mmol} / \mathrm{l}$ acetate/citrate buffer, $1.3 \mathrm{mmol} / \mathrm{l} \mathrm{H}_{2} \mathrm{O}_{2}, \mathrm{pH}$ 6.0) served as substrate. The product formation at $25^{\circ} \mathrm{C}$ was quantified after $20 \mathrm{~min}$ at $620 \mathrm{~nm}$. All washing procedures were identical in the subsequent tests.

\section{Antibody assay}

Pipette $100 \mu l$ antibody solution (rabbit anti-human fibronectin, diluted 1:2000 with phosphate buffer (i)) into the wells and incubate for $16 \mathrm{~h}$ at $4{ }^{\circ} \mathrm{C}$ for adsorption. Wash the plates three times with buffer (iii), then add a sample of $150 \mu$ l (diluted in buffer (ii)). For plasma, dilution to $1: 10000$ is necessary. Incubate the test mixture for $2.5 \mathrm{~h}$ at $25^{\circ} \mathrm{C}$ and wash three times with buffer (iii). Add $125 \mu$ l peroxidase labeled antibody ( $1: 1000$ diluted in buffer (ii)), incubate for one hour at $25^{\circ} \mathrm{C}$ and wash again three times with buffer (iii). Add $125 \mu \mathrm{l}$ substrate solution and measure the product formation as described above.

\section{Heparin assay}

Transfer $100 \mu \mathrm{l}$ of heparin solution $(100 \mathrm{U} / 1=0.6 \mathrm{~g} / 1$ in phosphate buffer (i)) into the wells as described above. Add $120 \mu$ sample material (dilution in buffer (ii); for plasma samples $1: 1000$ ). Further procedure as above.

\section{Fibrin assay}

Bovine fibrin is used as ligand. For this purpose, the microtitre plate is coated with fibrinogen, which is subsequently degraded to fibrin by thrombin. Since the fibrinogen preparation is contaminated with fibronectin, and hence cross-reacts with the antibody used, fibrinogen must be purified by affinity chromatography on gelatine-sepharose (see above).

Place $100 \mu \mathrm{l}$ purified fibrinogen solution $(0.1 \mathrm{~g} / 1$ in phosphate buffer (i)) into the wells and incubate over $3 \mathrm{~h}$ at $25^{\circ} \mathrm{C}$ in a moist chamber. After triple washing add $125 \mu \mathrm{l}$ thrombin solution $(0.4 \mathrm{U} / \mathrm{ml}$ in phosphate buffer (i)) and incubate the plates for $16 \mathrm{~h}$ at $4^{\circ} \mathrm{C}$. After finishing the washing steps as described above, add $120 \mu$ l diluted sample (in phosphate buffer (ii)); for plasma samples dilute 1:100 and proceed as described.

\section{Carboxyl group-modified IgG assay}

Human immunoglobulin IgG is modified at the carboxylgroups $\left(\mathrm{IgG}_{\mathrm{mod}}\right)$ by coupling glycine ethyl ester to the protein in the presence of carbodiimide $(9,17)$. Add $100 \mu \mathrm{l}$ of the modified IgG (10 mg/l in phosphate buffer (i)) as ligand to the solid phase. After washing, pipette $120 \mu$ diluted sample (plasma $1: 1000$ ) into the wells and incubate for $90 \mathrm{~min}$. In this test, add $2.5 \%$ (by vol.) rabbit serum to the enzyme-labeled antibody in order to avoid the nonspecific binding of the antibody to the modified IgG. The further quantification of binding is carried out as described.

\section{Gelatine assay}

Cover the microtitre plates with $100 \mu \mathrm{l}$ gelatine solution $(2.5 \mathrm{~g} / \mathrm{l}$ in phosphate buffer (i)). The further procedure is as described in the antibody assay. Plasma samples are diluted $1: 10000$.

For the analysis of plasma, EDTA-plasma with addition of $1 \mathrm{TIU} / \mathrm{ml}$ (trypsin inhibiting unit) aprotinin (Trasylol®) is generally used. For the comparative immunoturbidimetric fibronectin quantification, the 'Fibronectin' test kit from Boehringer (Mannheim, FRG) is used.

\section{Results}

As a basis for the following function-specified binding assays, we determined fibronectin in the ELISA test on microtitre plates (antibody assay). We used both purified fibronectin as well as plasma samples. With both materials, the fibronectin concentration can be quantified over a concentration range of $1 \mu \mathrm{g} / \mathrm{l}$ to 32 $\mu \mathrm{g} / \mathrm{l}$. This means a detection limit of $0.16 \mathrm{ng}$ fibronectin. The typical shape of the standard curve is shown in figure 1. In this as well as the other systems, the absorbance of the lowest detectable fibronectin concentration is defined as the threefold standard deviation of the blank value.

Since the immunological reactivity of fibronectin cannot provide reliable information on alterations of defined fibronectin functions, we developed different ELISA-equivalent procedures, each one quantifying a specific fibronectin binding property. In all assays the microtitre plates were first coated with the specific ligand, then incubated with the fibronectin-containing sample. The ligand-bound fibronectin was quantified by a peroxidase-labeled anti-fibronectin antibody. After lyophilisation, all ligand-coated carriers can be stored at $4^{\circ} \mathrm{C}$ for at least eight weeks.

The collagen-binding capacity of fibronectin was tested in the gelatine assay. Figure 1 shows the typical calibration curve. The measuring range extends from $1.6 \mu \mathrm{g} / 1-50 \mu \mathrm{g} / 1$. This corresponds to a detection limit of $0.2 \mathrm{ng}$ fibronectin per well.

The fibronectin-heparin affinity was quantified via an appropriate test system. The measuring range here was $200 \mu \mathrm{g} / \mathrm{l}-125 \mathrm{mg} / \mathrm{l}$ (detection limit $24 \mathrm{ng}$ fibronectin).

We found the fibrin binding assay to have the lowest sensitivity $(3 \mathrm{mg} / \mathrm{l}-200 \mathrm{mg} / \mathrm{l}$; detection limit $0.36 \mu \mathrm{g}$ fibronectin).

Since fibronectin possesses an additional binding site for carboxyl group-modified proteins in its C-terminal domain, we developed an assay for these ligands. As can be seen from figure 1 , we found that this assay gave the widest measuring range (25 $\mu \mathrm{g} / 1-1.6 \mathrm{mg} / \mathrm{l}$ ) and a good limit of detection (3.0 $\mathrm{ng}$ fibronectin). 


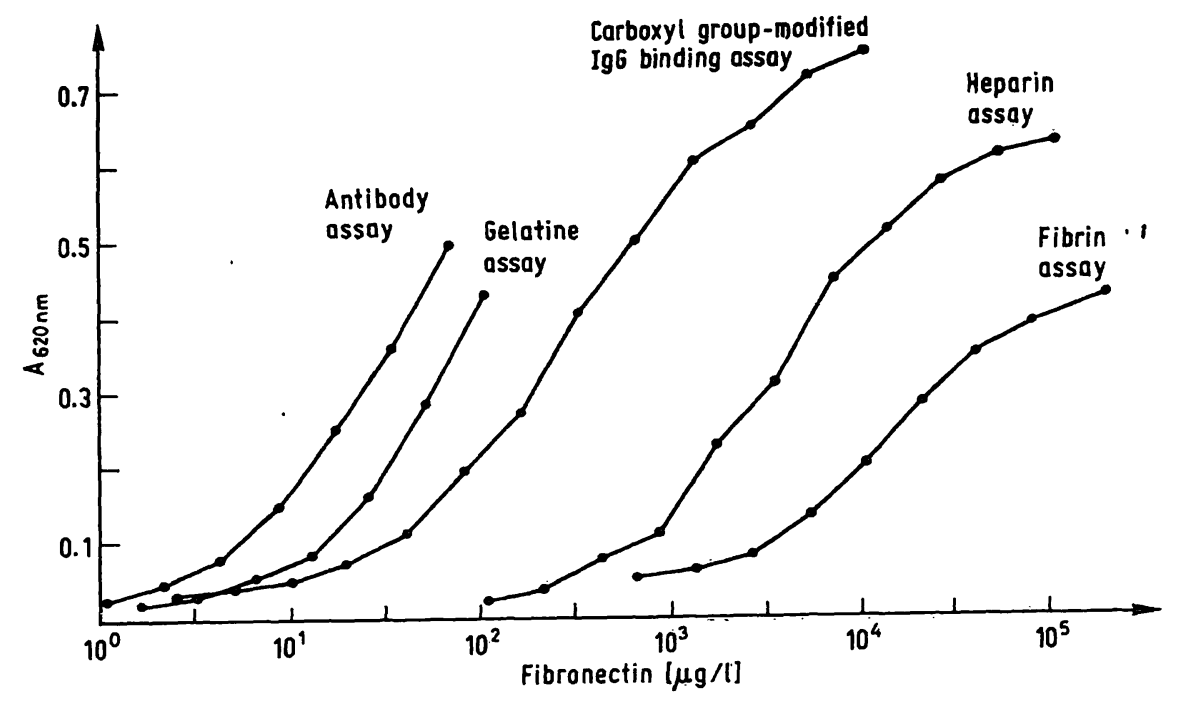

Fig. 1. Measurement ranges for concentration and binding affinity analysis of fibronectin.

The various ELISA test procedures detect the concentration (antibody assay) or binding affinities (gelatine assay, carboxyl group-modified IgG binding assay, heparin assay, fibrin assay) in different measurement ranges. Purified fibronectin served as sample material in each case. Each measurement value corresponds to the mean value of triple determination. Corresponding analysis of plasma can be carried out by means of the available reference curves.

In table 1 , the results on within-run and between-run imprecision are summarized for all tests mentioned. We obtained identical results when using both purified fibronectin or plasma. To plot reference standard curves and to check the accuracy, we used commercial fibronectin standards (Boehringer Mannheim) as well as fibronectin we had purified ourselves. The quantitative protein assay of the purified fibronectin corresponded exactly with the fibronectin concentration determined immunologically with the commercial fibronectin standard. Recovery trials with purified fibronectin and commercial fibronectin standards showed a mean deviation of the target value of $3 \%$.

For optimization of the technique, we examined, for all test systems, the influence of ionic strength and $\mathrm{pH}$ on the binding of fibronectin bound to the solid

Tab. 1. Within-run and between-run imprecision of the fibronectin assays. The studies were performed with one lot of ligand-coated microtitre plates. There are only non-significant differences from lot to lot. For the assays, purified fibronectin was used. Each value is the mean of seven measurements.

\begin{tabular}{llllll}
\hline Assay & $\begin{array}{l}\text { Within-run } \\
\text { imprecision } \\
\text { fibronectin }\end{array}$ & $\begin{array}{l}\text { Between-run } \\
\text { imprecision } \\
\text { fibronectin }\end{array}$ & \\
\cline { 2 - 3 } \cline { 5 - 7 } & $\begin{array}{l}\overline{\mathrm{x}} \pm \mathrm{s} \\
(\mathrm{mg} / \mathrm{l})\end{array}$ & $\begin{array}{l}\mathrm{CV} \\
(\%)\end{array}$ & $\begin{array}{l}\overline{\mathrm{x}} \pm \mathrm{s} \\
(\mathrm{mg} / \mathrm{l})\end{array}$ & $\begin{array}{l}\mathrm{CV} \\
(\%)\end{array}$ \\
\hline Antibody & $350 \pm 9.5$ & 2.7 & & $361 \pm 12$ & 3.4 \\
Gelatine & $344 \pm 8.3$ & 2.4 & & $358 \pm 13$ & 3.7 \\
Fibrin & $881 \pm 40$ & 4.6 & & $902 \pm 69$ & 7.7 \\
IgG & $625 \pm 31$ & 5.0 & & $604 \pm 38$ & 6.3 \\
Heparin & $507 \pm 25$ & 4.9 & & $521 \pm 39$ & 7.5 \\
\hline
\end{tabular}

phase. All systems showed an optimal binding in phosphate buffer containing bovine serum albumin and EDTA and a broad $\mathrm{pH}$ optimum between $\mathrm{pH}$ 7.0 and 8.0. An exception was the $\operatorname{IgG}_{\text {mod }}$ assay. Here, we found a $\mathrm{pH}$ optimum at 6.0 .

According to various investigations, raised ion concentrations will abolish heparin-fibronectin binding. The addition of $0.15 \mathrm{~mol} / 1 \mathrm{NaCl}$ to the phosphate buffer leads to an almost complete loss of fibronectin binding to solid phase-bound heparin (data not shown here).

To check the binding specificities, we performed assays in the presence of heparin, fibrinogen or gelatine (fig. 2). These tests were carried out with purified fibronectin. The fibrin assay was influenced by fibrinogen, but not by gelatine or heparin. It has to be mentioned here that the affinity of native fibrinogen to fibronectin compared with that of fibrin is only three percent (data' not shown here). The gelatine assay was inhibited by gelatine and remained unaffected by heparin and fibrinogen. The heparin assay was moderately stimulated by heparin, highly activated by gelatine and not affected by fibrinogen. The binding assay for modified IgG was not altered by any of the tested substances. Native IgG did not influence any of the tests mentioned.

Figure 3 illustrates the concentration-dependent influence of gelatine, fibrinogen and heparin on the gelatine binding test. Soluble gelatine inhibited the binding of fibronectin to solid phase-bound gelatine in a concentration-dependent manner. On the other hand, heparin did not have any effect. This means 


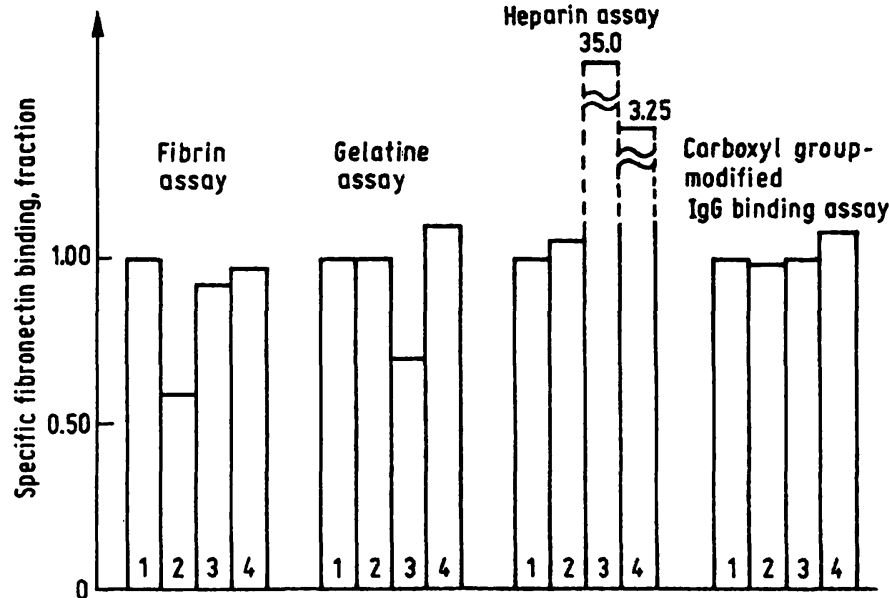

Fig. 2. Interference of dissolved substances in the fibronectin binding assays.

Column (1) represents in all binding assays the control value. In the columns (2) $1.0 \mathrm{~g} / 1$ fibrinogen, (3) $1.0 \mathrm{~g} / \mathrm{l}$ gelatine and (4) $1 \mathrm{U} / \mathrm{ml}$ heparin is added to the purified fibronectin. Fibronectin concentration (always set as 1.00 ) in the assays: fibrin assay: $10 \mathrm{mg} / \mathrm{l}$, gelatine assay: $30 \mu \mathrm{g} / \mathrm{l}$, heparin assay: $5 \mathrm{mg} / \mathrm{l}, \mathrm{IgG}$ assay: $70 \mu \mathrm{g} / \mathrm{l}$.

that dissolved heparin did not influence the gelatine binding assay, but soluble gelatine massively promoted fibronectin binding to coated heparin. For further verification of this finding, figure 4 demonstrates the concentration-dependent influence of gelatine or heparin as well as the combined addition of

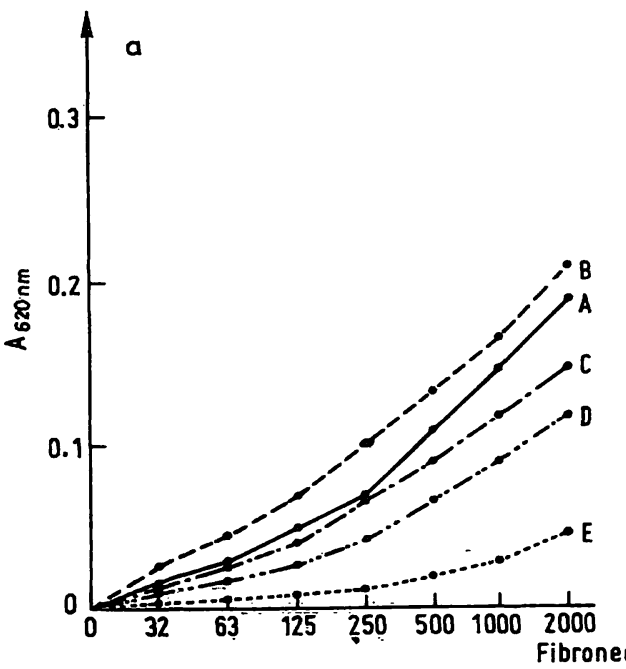

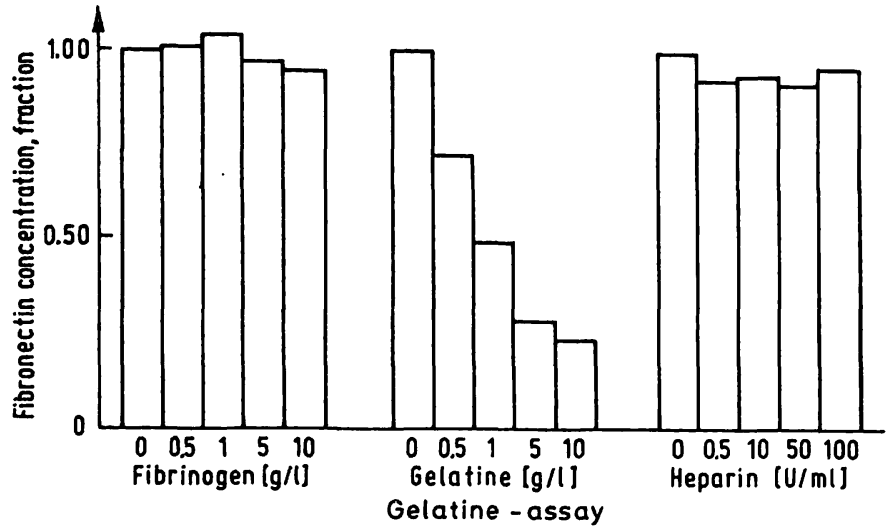

Fig. 3. Influence of dissolved fibrinogen, gelatine or heparin on the gelatine binding assay.

Purified fibronectin serves as standard $(30 \mu \mathrm{g} / 1=1.00)$. The specified concentrations of the tested substances (abscissa) relate to the initial sample material (concentration in the test: $1 \times 10^{-4}$ ).

both substances on the affinity of fibronectin for solid phase-bound heparin. A low concentration of dissolved heparin promoted the binding of fibronectin to the solid phase-bound heparin. On the other hand, higher concentrations inhibited binding of fibronectin to the heparin-coated carrier. A quite different picture is shown in the 'gelatine-activation' of heparin-fibronectin binding. Gelatine activated this binding, and the activation showed saturation kinetics.

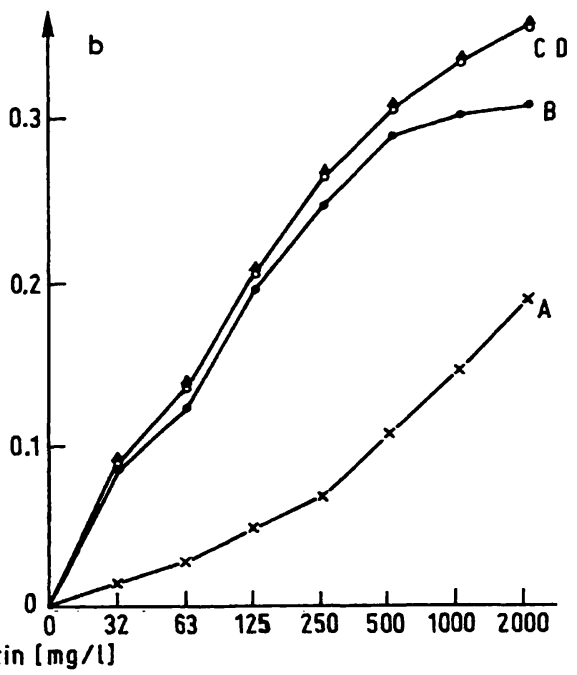

Fig. 4. Influence of dissolved gelatine and heparin on the heparin binding assay.

a) Influence of dissolved heparin

$(\longrightarrow$ control (A)

(- - ) $10 \mathrm{U} / \mathrm{ml}$ heparin (B)

$(\cdot-\cdot-) \quad 50 \mathrm{U} / \mathrm{ml}$ heparin (C)

(.-..) $100 \mathrm{U} / \mathrm{ml}$ heparin (D)

$(\cdots \cdots) \quad 500 \mathrm{U} / \mathrm{ml}$ heparin (E)

b) Influence of dissolved gelatine

$(x-x)$ control (A)

$(\bullet-\bullet) \quad 10 \mathrm{mg} / \mathrm{l}$ gelatine (B)

(O-0) $50 \mathrm{mg} / \mathrm{l}$ gelatine (C)

$(\Delta-\Delta) 100 \mathrm{mg} / \mathrm{l}$ gelatine (D)

The specified concentrations of heparin and gelatine relate to the initial sample material (concentration in the test: $1 \times$ $10^{-2}$ ). Simultaneous addition of gelatine and heparin shows the binding kinetics of $B$. 
To check the immune reactivity and bioactivity of fibronectin fragments, we incubated fibronectin with thermolysin for various periods of time. The resulting polypeptide chains were separated by polyacrylamide gel electrophoresis and transferred to nitrocellulose membranes (Western blot). Figure 5 shows that thermolysin treatment of fibronectin leads, in time-dependent fashion, to an increasing cleavage of the protein. Whereas some polypeptide fragments down to a molecular weight of $M_{\mathrm{r}}=\mathrm{ca} .30000$ were still immunoreactive, various larger fragments did not react with anti-fibronectin. To support this finding, thermolysintreated fibronectin was separated on a hydroxyapatite column. With this technique it is possible inter alia to isolate the gelatine domain $\left(M_{\mathrm{r}}=43000\right)$ (18). The isolated peptide fragment was seen in the polyacrylamide gel electrophoresis after Coomassie staining at the expected molecular weight; however, it could not be demonstrated immunologically in the Western blot (fig. 5). The isolated peptide likewise did not react in the gelatine assay (data not shown here). However, we have indications that this isolated fibronectin fragment can be quantified on the basis of its carbohydrate moiety by an enzyme-linked lectin assay (manuscript in preparation).

Data presented in figure 6 document the influence of proteolysis on the binding assays and demonstrate at the same time whether fibronectin cleavage products

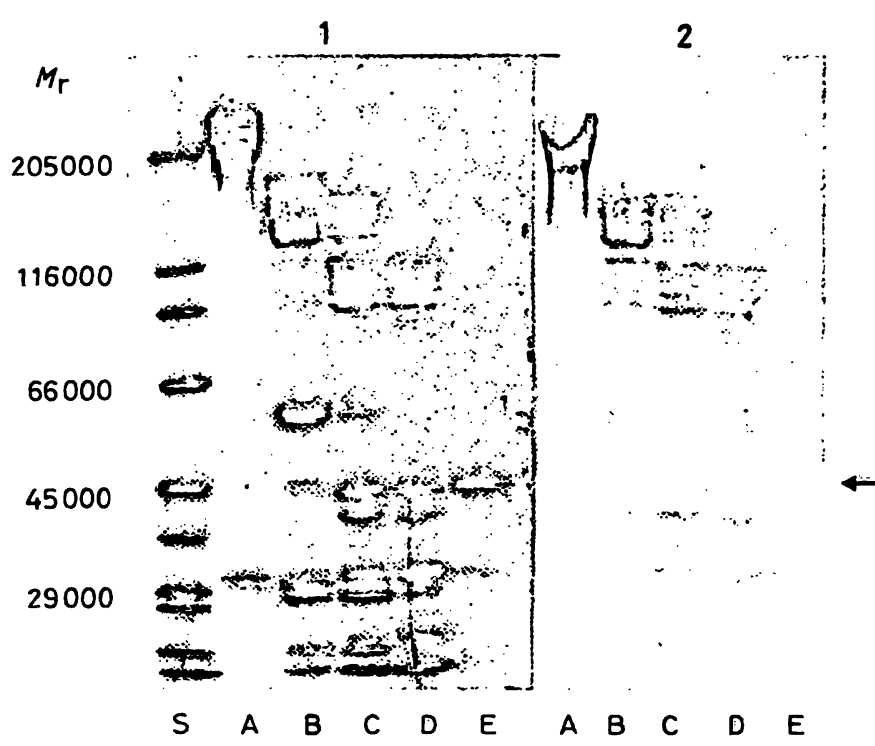

Fig. 5. Identification of fibronectin fragments after limited proteolysis.

1: Polyacrylamide gel electrophoresis after Coomassie staining. $A=15 \mathrm{~s}, B=10 \mathrm{~min}, C=3 \mathrm{~h}, D=20 \mathrm{~h}$ after beginning of the thermolysin proteolysis of fibronectin; $\mathrm{E}=$ isolated gelatine binding domain of fibronectin;

$\mathrm{S}=$ molecular weight standards.

2: Material as in 1. Representation of the immunoreactive polypeptides with anti-fibronectin in the Western blot (see Methods). ( $\leftarrow)$ The gelatin binding domain $\left(M_{\mathrm{r}}=43000\right)$ shows no immunoreactivity.

have false positive or false negative effects on the test systems. In the antibody-based assay the thermolysininduced proteolysis of fibronectin leads to a massive
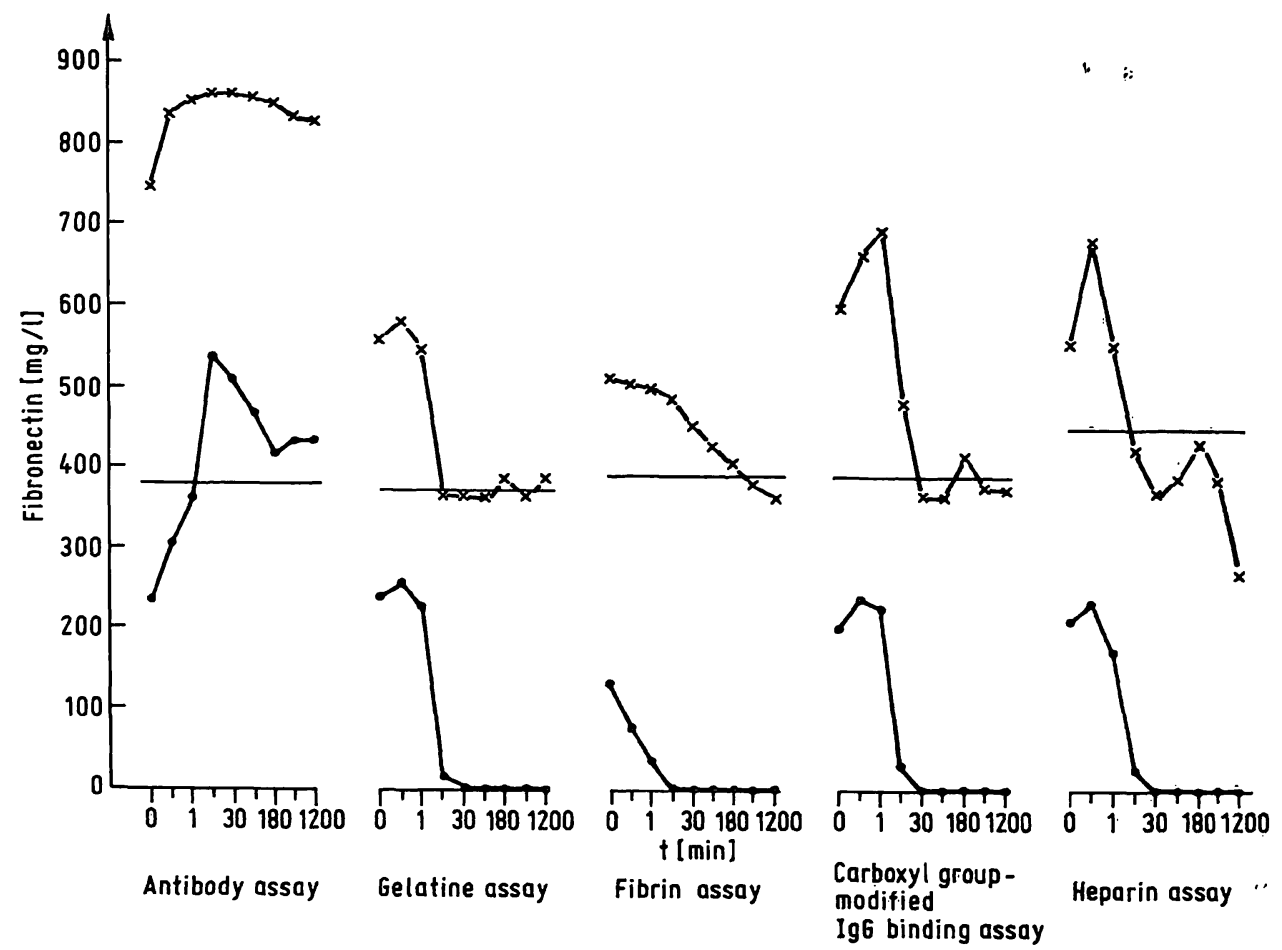

Fig. 6. Proteolysis-dependent influence on the determination of fibronectin concentration.

The thermolysin-catalysed proteolysis of purified fibronectin. is stopped by addition of EDTA at defined times (15 s, $1 \mathrm{~min}, 30 \mathrm{~min}, 1 \mathrm{~h}, 3 \mathrm{~h}, 5 \mathrm{~h}, 20 \mathrm{~h}$ ). The samples are quantified in the individual assays, ( -0$)$ : antibody assay, gelatine assay, fibrin assay, carboxyl group-modified IgG binding assay, heparin assay. -

The fibronectin fragments are mixed with intact (purified) fibronectin $(x-x)$. The horizontal bars correspond to the initial concentration or binding activities of the intact molecule (with consideration of the dilution factor). 
enhancement of the measured concentration. We obtained almost identical false positive results with the commercial turbidimetric fibronectin-assay. Proteolysis with trypsin or subtilisin interfered similarily.

Compared with the antibody assay, the functional binding tests showed a quite different picture. After 30 min of thermolysin treatment, all binding affinities were no longer detectable.

To examine the question of whether fibronectin fragments influence the functional quantification of intact fibronectin, we mixed equal parts of native fibronectin with fibronectin subjected to limited proteolysis. Fibronectin fragments did not have any activating or inhibiting effect on the gelatine, fibrin or IgG assay (fig. 6). On the other hand, in the heparin binding test the low molecular weight fibronectin fragments (after long thermolysin treatment) had a significant inhibitory effect on the heparin binding activity of native fibronectin.

In order to show to what extent the techniques presented here for human fibronectin can be transferred to investigations with fibronectin of animal origin, we tested plasma from rat, mouse, guinea pig, hamster, calf, dog, sheep and rabbit. In the Western blot, all samples, except rabbit plasma, showed immunoreactivity with anti-human fibronectin. We found no cross-reactivity with other proteins. Table 2 demonstrates that, with the exception of the fibrin binding assay, the ligand-specific test systems can be applied to fibronectin studies in other animal species.

Tab. 2. Species-specificity of the fibronectin assays. In all assays EDTA plasma and anti-human fibronectin were used. Predilutions of the plasma samples are described in the text. The concentration and binding activities are calculated from the standard calibration curves (see fig. 1). All values are the mean of triple determinations ( $-\equiv$ no binding capacity).

\begin{tabular}{lccccc}
\hline & \multicolumn{3}{l}{ Fibronectin (mg/l) } \\
\cline { 2 - 6 } & $\begin{array}{l}\text { Anti- } \\
\text { body } \\
\text { assay }\end{array}$ & $\begin{array}{l}\text { Fibrin } \\
\text { assay }\end{array}$ & $\begin{array}{l}\text { Heparin } \\
\text { assay }\end{array}$ & $\begin{array}{l}\text { IgG } \\
\text { assay }\end{array}$ & $\begin{array}{l}\text { Gela- } \\
\text { tine } \\
\text { assay }\end{array}$ \\
\hline Man & 122 & 59 & 103 & 120 & 119 \\
Rat & 90 & $<5$ & 40 & 30 & 125 \\
Mouse & 85 & $<5$ & 122 & 12 & 126 \\
Guine pig & 122 & $<5$ & 73 & 17 & 147 \\
Hamster & 82 & $<5$ & 105 & 12 & 147 \\
Rabbit & - & - & - & - & - \\
Calf & 121 & $<5$ & 197 & 33 & 187 \\
Dog & 416 & $<5$ & 227 & 53 & 593 \\
Sheep & 91 & $<5$ & 184 & 18 & 148 \\
\hline
\end{tabular}

\section{Discussion}

In the present paper we describe highly sensitive ELISA techniques for quantification of fibronectin, together with studies on binding activities in biological materials. At the same time, we show that in many cases erroneous results are to be expected with merely immunological assays of the fibronectin concentration. Hitherto, the most frequently applied methods for the determination of fibronectin concentration in plasma, cerebrospinal fluid, synovial fluid or ascites have been immunological assays based on turbidimetry, laser nephelometry or rocket immunoelectrophoresis $(21,22,23)$. Nevertheless, problems in the quantification which greatly restrict the reliability of these methods have been known for some time (24). A further major disadvantage of the immunological quantification is that these techniques cannot allow appraisals of the functional integrity of the molecule. Both these facts probably explain the contradictory opinions on the diagnostic and pathobiochemical relevance of fibronectin in various diseases $(25,26)$. In view of these problems, other study groups have already presented suggestions for the functional analysis of fibronectin $(15,27,28,29)$. In these gelatine and opsonin function-specified tests of fibronectin, the possible interferences of fibronectin domains have not been investigated. Other studies, however, show that heparin leads to an exposure of active domains via an alteration in conformation of the fibronectin molecule $(30,31)$.

The individual techniques described here are characterized by a high degree of sensitivity, good reproducibility and accuracy as well as good practicability. The antibody assay is not interfered with by other plasma proteins or other physiological plasma constituents. However, it must be born in mind that according to our results, as already suspected by other authors (24), proteolytic fibronectin fragments also expose increased amounts of immunoreactive determinants, so that fibronectin concentrations are over-estimated. Other fibronectin fragments are no longer immunoreactive (32). We confirm these findings.

The question of the extent to which proteolytic fragments have false positive or false negative effects on the function tests could also be clarified. We show that all binding affinities are destroyed by sufficiently intensive exposure to proteases. At the same time, we document in additional experiments with intact fibronectin that late fibronectin fragments do not disturb the binding capacity of native fibronectin. An exception is the heparin assay. It shows a moderate inhibition at a high fragment concentration. 
To our knowledge, the described test systems present the widest spectrum for a functional analysis of fibronectin. At the same time, they provide the chance of testing interference of the individual ligands. For the quantification of the collagen binding capacity we used gelatine from calf skin as ligand. Other authors have shown that various collagen types possess a differentiated fibronectin binding behaviour (33). Since the collagen binding sites are localized in the two $\mathrm{N}$-terminal domains of the fibronectin molecule and since fibrin and heparin are also bound in this region, it had to be checked in particular whether these two substances interfere with the gelatine binding assay. It becomes evident from our studies that soluble gelatine competitively inhibits the binding of fibronectin to the solid phase-bound gelatine. However, neither heparin nor fibrinogen influence the test. A highly function-specific test is thus provided. So far, it is not possible to assess how or to what extent the two domains with collagen binding affinity are involved in the gelatine test.

Fibronectin is bound covalently in the N-terminal domain to the $\alpha$-chain of the fibrin monomer via the transglutaminase activity of factor XIII. This binding has no significance in our investigations with purified fibronectin. In addition, the neighboring domain binds fibrin, and it binds fibrinogen with reduced affinity. Since collagen is also bound in this region, our demonstration that the fibrin assay is preferentially inhibited by fibrinogen, and to a lesser extent also by gelatine, is understandable.

The binding affinity of fibronectin to carboxyl groupmodified IgG appears to be especially interesting, since only the C-terminal domain is thought to be responsible for this affinity (9). Otherwise only fibrin (which does not interfere in any way with this test system) is known to bind at this site. The specificity of this binding also becomes evident, in that native IgG does not have any influence. In clinical terms, this test will be important, since there are indications that the opsonin function of fibronectin involves this binding type (34).

Glycosaminoglycans are bound by two domains of the intact fibronectin molecule. An additional binding domain is rendered reactive by limited proteolysis (8). Whereas native fibronectin almost exclusively binds heparin fragments of fibronectin can also bind other proteoglycans with variable affinity. In the present investigation, we were concerned only with heparin. The N-terminal heparin-binding site is $\mathrm{Ca}^{2+}$ inhibited, it can be assumed that mainly the $\mathrm{N}$-terminal binding site is detected in this heparin assay. Fibrinogen does not interfere in the heparin assay.

Soluble heparin promotes fibronectin affinity to solid phase-bound heparin at low concentration and inhibits this competitively at higher concentrations. However, soluble gelatine induces a very impressive, concentration-dependent enhancement of fibronectin binding to the carrier-bound heparin. In cell adhesion studies, an equivalent effect has already been observed and designated as "substrate activation". Heparin also significantly stimulates the fibronectin-mediated uptake of gelatine-coated particles by macrophages (36). Thus, we have positive indications that the results of our test system can be transferred to studies in cell biology.

Further investigations are required to show to what extent the effects observed here are also relevant for in vivo functional regulation. This not only applies to cell biological studies with use of additional ligands and inhibitors, but also to the possible therapeutic use of fibronectin in various 'active forms'. Positive and negative reports on the use of fibronectin in shock treatment and wound healing so far indicate that further basic work is necessary $(37,38)$. Diagnostic use of the fibronectin function tests described here also open new possibilities in the context of inflammation and tumour diagnosis. Orientative investigations on plasma samples of patients with liver diseases as well as of tumour patients suggest the existence of marked differences and variations of the fibronectin functional spectrum.

Finally, it is documented that the test system can also be used for functional analysis of fibronectin of other animal species, when using the appropriate animal fibronectin standards. Due to the high degree of assay sensitivities, only minimal sample amounts are needed. At the same time, these investigations already show that fibronectins from different species have a significantly different functional spectrum, showing comparable concentrations in the antibody assay (except $\mathrm{dog}$ ) and significantly differing ratios between the specific binding assays. 


\section{References}

1. Yamada, K. M. (1983) Ann. Rev. Biochem. 52, 761-799.

2. Ruoslahti, E., Engvall, E. \& Hayman, E. G. (1981) Collagen Res. 1, 95-128.

3. Mosesson, M. W. \& Amrani, D. L. (1980) Blood 56, 145-158.

4. Wagner, D. D., Ivatt, R., Destree, A. T. \& Hynes, R. O. (1981) J. Biol. Chem. 256, 11708-11715.

5. Krusius, T., Fukuda, M., Dell, A. \& Ruoslahti, E. (1985) J. Biol. Chem. 260, 4110-4116.

6. Ali, I. U. \& Hunter, T. (1981) J. Biol. Chem. 256, $7671-7677$.

7. Sekiguchi, K., Hakomori, S., Funahashi, M., Matsumoto, I. \& Seno, N. (1983) J. Biol. Chem. 258, 14359-14365.

8. Yamada, K. M. (1982) Biochemistry of Fibronectin. In: The Glycoconjugates, vol. III, Academic Press, New York, pp. $331-362$.

9. Vuento, M., Sekiguchi, K. \& Korkolainen, M. (1983) Biochem. J. $215,613-616$.

10. Julkunen, I., Vartio, T. \& Keski-Oja, J. (1984) Biochem. J. $219,425-428$.

11. Pussell, B. A., Peake, P. W., Brown, M. A. \& Charlesworth, J. A. (1985) J. Clin. Invest. 76, 143-148.

12. Pott, G., Voss, B., Lohmann, J. \& Zündorf, P. (1982) J. Clin. Chem. Clin. Biochem. 20, 333-335.

13. De Russe, J., Colombat, P., Lavoix, X. \& Bardos, P. (1985) Clin. Chim. Acta 145, 49-58.

14. Schölmerich, J., Volk, B. A., Köttgen, E., Ehlers, S. \& Gerok, W. (1984) Gastroenterology 87, 1160-1164.

15. Doran, J. E., Callaway, B. D., Reese, A. C., Wynn, J. J. \& Mansbeeger, A. R. (1983) Vox Sang. 45, 243-251.

16. Mosesson, M. W. \& Umfleet, R. A. (1970) J. Biol. Chem. $245,5728-5736$.

17. Carraway, K. L. \& Koshland, D. E. (1972) Methods Enzymol. 25, 616-623.

18. Zardi, L., Carnemoa, B., Balza, E., Borsi, L., Castellani, P., Rocco, M. \& Siri, A. (1985) Europ. J. Biochem. 146, $571-579$.

19. Towbin, H., Staehelin, T. \& Gordon, J. (1979) Proc. Natl. Acad. Sci. (U. S. A.) 76, 4350-4354.
20. Laemmli, U. K. (1970) Nature $227,680-685$.

21. Gressner, A. M. \& Wallraff, P. (1981) J. Clin. Chem. Clin. Biochem. 19, 1213-1215.

22. Van Helden, W. C. H., Kok-Verspuy, A., Harff, G. A. \& van Kamp, G. J. (1985) Clin. Chem. 31, 1182-1184.

23. Engvall, E. (1986) Fibronectin. In: Methods of Enymatic Analysis (Bergmeyer, H. U., ed.) 3. Ed., Verlag Chemie Weinheim, pp. 201-211.

24. Bykowska, K., Wegrzynowicz, Z., Lopaciuk, S. \& Kopec, M. (1985) Thrombosis and Haemostasis 53, 377-380.

25. Maunder, R. J., Harlan, J. M., Pepe, P. E., Paskell, S., Carrico, C. J. \& Hudson, L. D. (1984) J. Lab. Clin. Med. $104,583-590$.

26. Cembrowski, G. S. \& Mosher, D. F. (1984) Thromb. Res. 36, 437-445.

27. Selmer, J., Eriksen, H. \& Clemmensen, I. (1984) Scand. J. Clin. Lab. Invest. 44, 57-63.

28. Fenger, M. (1984) Scand. J. Clin. Lab. Invest. 44, $541-547$.

29. Chang, M., Chin, S. \& Horowitz, B. (1985) Vox Sang. 48, 217-228.

30. Richter, H., Wendt, Ch. \& Hörmann, H. (1985) Biol. Chem. Hoppe Seyler 366, 509-514.

31. Bentley, K. L., Klebe, R. J., Hurst, R. E. \& Horowitz, P. M. (1985) J. Biol. Chem. 260, 7250-7256.

32. Vartio, T., Zardi, L., Balza, E., Towbin, H. \& Vaheri, A. (1982) J. Immun. Meth. 55, 309-318.

33. Engvall, E., Ruoslahti, E. \& Miller, E. J. (1978) J. Exp. Med. 92, 1584-1595.

34. Czop, J. K., Kadish, J. L., Zepf, D. M., Austen, K. F. (1985) J. Immunol. 134, 1844-1850.

35. Hayashi, M. \& Yamada, K. M. (1982) J. Biol. Chem. 257, $5263-5267$

36. Johannsson, S. \& Höök, M. (1984) J. Cell Biol. 98, 810-817.

37. Saba, T. M. (1982) Plasma fibronectin and hepatic Kupffer cell function. Progr. Liver Diseases Vol VII, Grune and Stratton Inc., pp. 109-131.

38. Aukburg, S. J. \& Kaplan, J. E. (1981) Adv. Shock Res. 6, $37-44$.

Prof. Dr. E. Köttgen

Institut für Klinische Chemie

Univ.-Klinikum Charlottenburg

Freie Universität Berlin

Spandauer Damm 130

1000 Berlin 19 
